\title{
Export and Import Demand Functions of Bangladesh: A Disaggregated Approach
}

\section{Mohammad Monirul Islam Sarker}

Centre for Economic Studies and Planning, Jawaharlal Nehru University, New Delhi, India

\section{Email address:}

monirbb@yahoo.co.uk

\section{To cite this article:}

Mohammad Monirul Islam Sarker. Export and Import Demand Functions of Bangladesh: A Disaggregated Approach. International Journal of Economics, Finance and Management Sciences. Vol. 6, No. 2, 2018, pp. 66-74. doi: 10.11648/j.ijefm.20180602.15

Received: March 22, 2018; Accepted: April 8, 2018; Published: May 18, 2018

\begin{abstract}
This study attempts to estimate the export and import demand functions of Bangladesh on a bilateral basis by using annual data from 1995-2015, Johansen cointegration test approach and vector error correction mechanism. The estimated results identify income as an influential determinant of both export and import demand of Bangladesh, while the influence of price is very limited. The price effect appears limited because Bangladesh's export prices for garments are already absolutely low, so changes in prices are less significant; while for imports, the impact of trade liberalization has been greater than changing world prices.
\end{abstract}

Keywords: Export and Import Demand, Bilateral Model, Cointegration Test, Error Correction Mechanism, Income and Price Elasticity

\section{Introduction}

The estimation of export and import demand functions is generally a useful exercise for a small open economy, such as that of Bangladesh. Trade openness in Bangladesh, as measured by the trade-GDP ratio, increased over the years from 27 per cent in 1995 to 37 per cent in 2015 (Figure 1). While the trade deficit reduced somewhat in recent years, it was an average of 6.7 per cent of GDP for the period 1995-
2015. Exports have been highly concentrated in a few products (Figure 2) and a few markets (Figure 3), although the composition of both has changed over time. In 2015, about 85 per cent of total exports were readymade garments that went mainly to the European Union and the United States. The export sectors, particularly the apparel industries, are highly dependent on the imports of industrial raw materials and capital machinery, which are imported mainly from China and India.

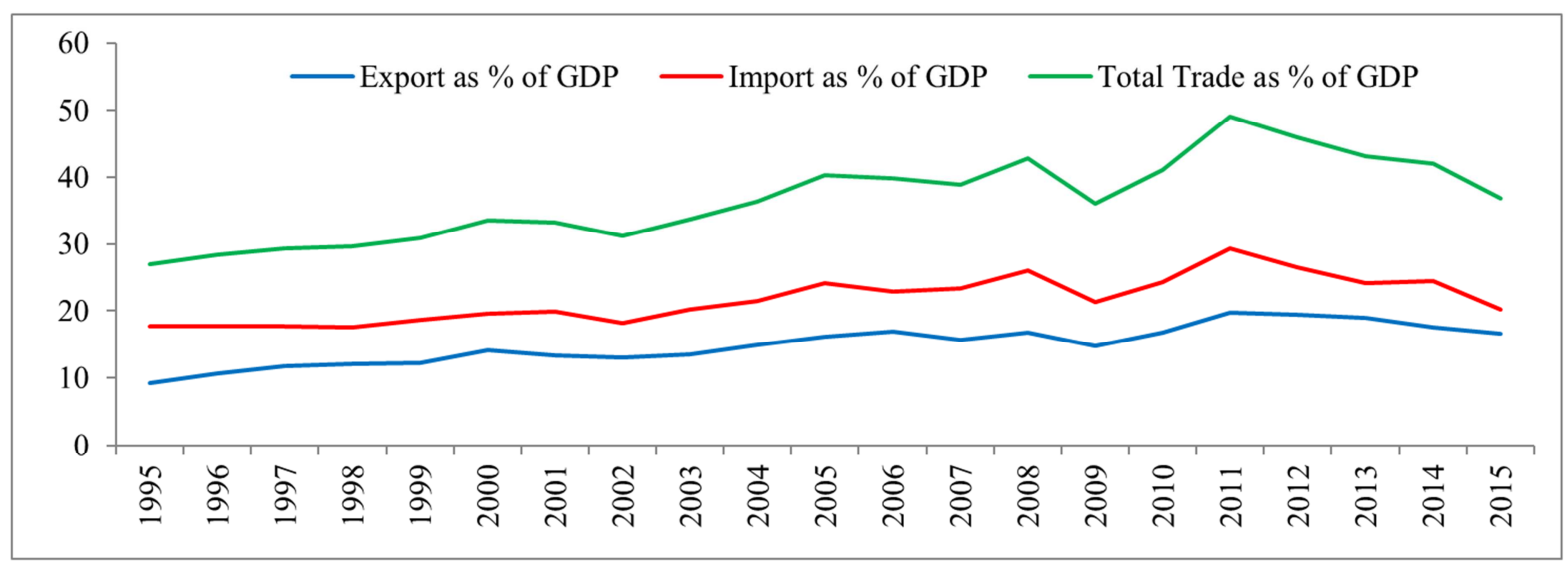

Source: Prepared on the basis of data from UNCTADstat.

Figure 1. Trade Openness in Bangladesh. 

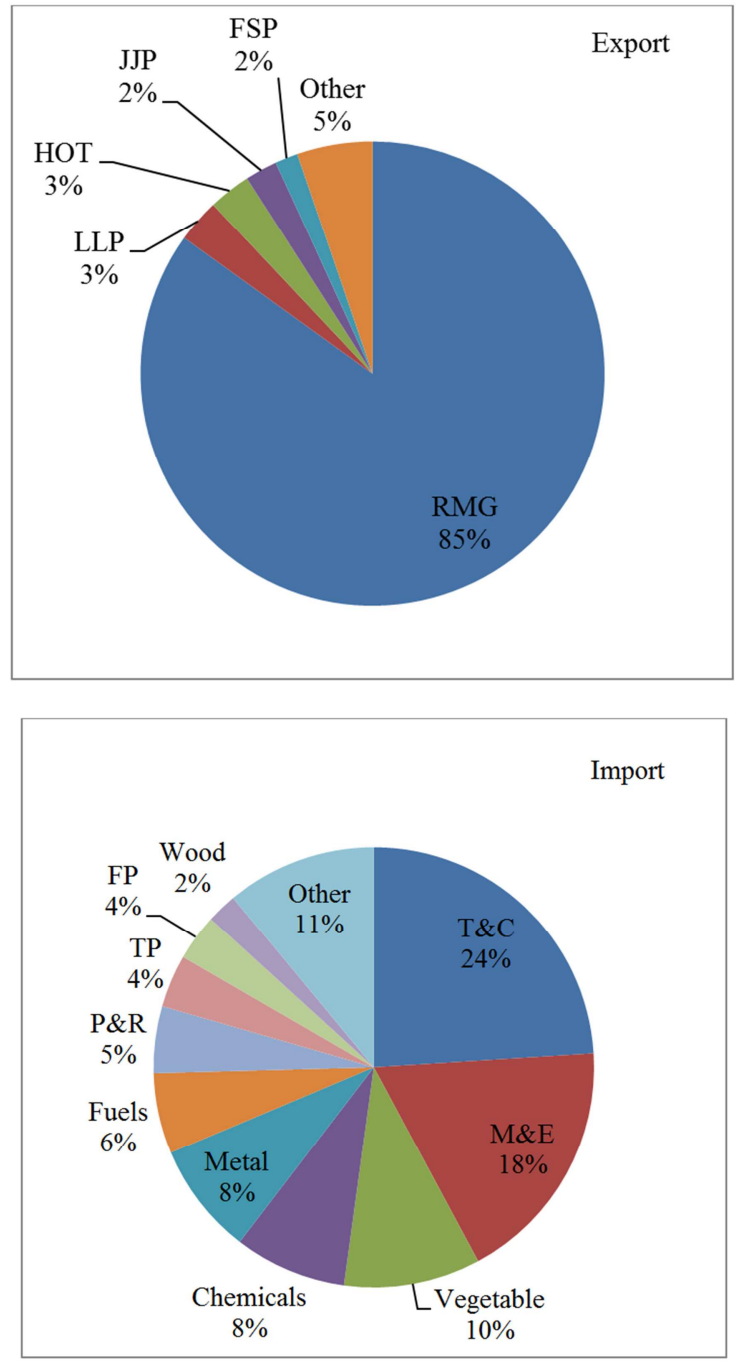

Figure 2. Product-wise Composition of Export and Import in 2015.

Note: $R M G=$ Readymade Garments; LLP $=$ Leather and Leather Products; HOT $=$ Home Textiles; JJP $=$ Jute and Jute Products; FSP $=$ Fish, Shrimps and Prawns; $\mathrm{T} \& \mathrm{C}=$ Textiles and Clothing; $\mathrm{M} \& \mathrm{E}=$ Machinery and Electronics; $\mathrm{TP}=$ Transportations; and $\mathrm{FP}=$ Food Products.

Source: Prepared on the basis of data from UN Comtrade.

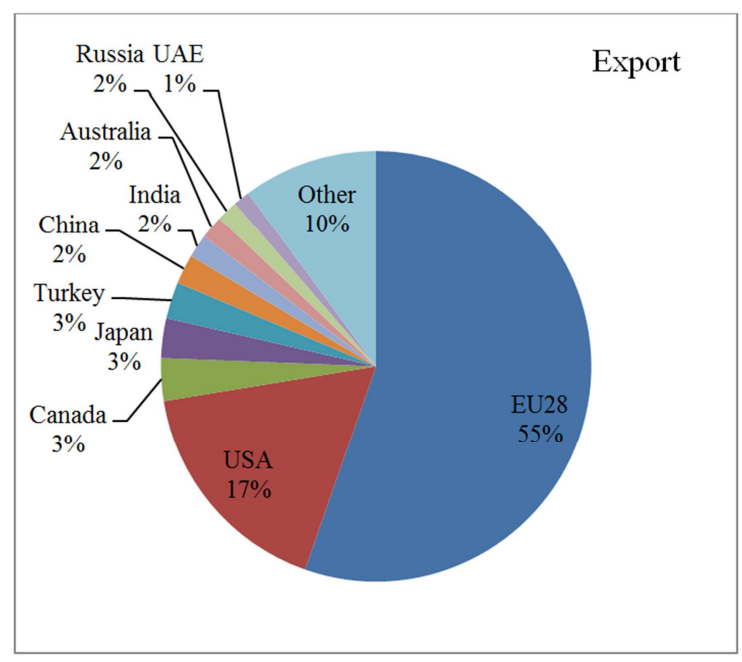

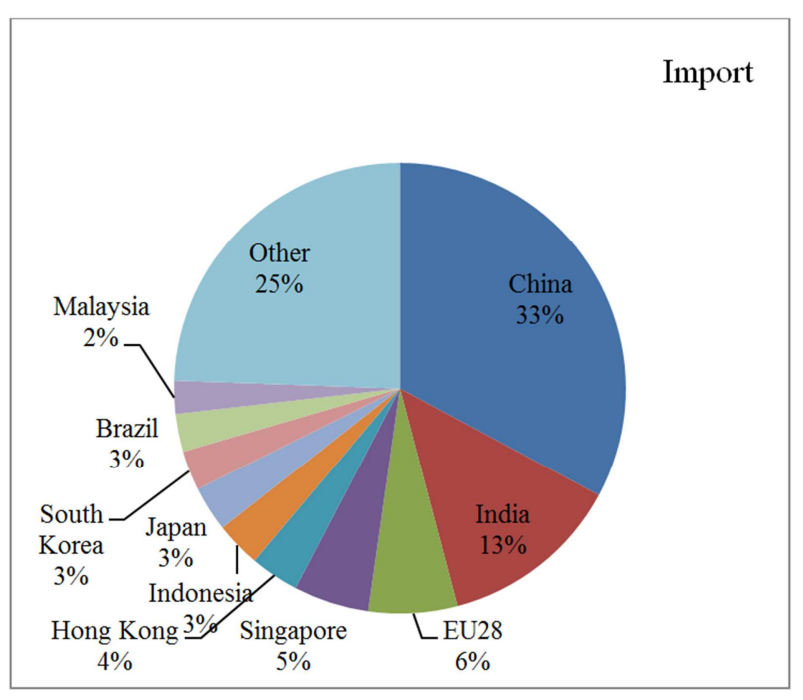

Source: Prepared on the basis of data from UN Comtrade.

Figure 3. Partner-wise Composition of Export and Import in 2015.

Two types of export and import demand functions are commonly estimated. In the aggregate approach, the value of total exports (to all recipients for all products) is the dependent variable in estimating the export demand function, and the value of total imports is the dependent variable in estimating the import demand function. For the explanatory variables, the aggregate approach typically uses the real effective exchange rate as a proxy for the relative export price and import price variables. The weighted average ${ }^{1}$ of partners' real income is the proxy for the income variable in the export demand function, and the real income of the reporting country is the income variable in the import demand function. In the disaggregated approach, the value of exports to a bilateral partner (for all products, a group of products or a single product) is used as the dependent variable in the export demand function and the value of imports from a bilateral partner (for all commodities, a group of commodities or a single commodity) is the dependent variable in the import demand function. The explanatory variables are the bilateral real exchange rate and the real income of the bilateral partner in the export demand function, and the bilateral real exchange rate and the real income of the reporting country in the import demand function.

The major shortcoming of the aggregate approach is its aggregation bias, in the sense that a significant coefficient with one partner may be offset by an insignificant coefficient with another partner, leading to no significance of the overall coefficient [7]. Since the external trade of Bangladesh is highly concentrated in a few trading partners, the aggregate model may suffer from this aggregation bias. Therefore, this study estimates bilateral export and import demand functions of Bangladesh with its major export and import partners

1 The weights are calculated on the basis of the value of export or import or trade (export + import) of the reporting country with its partners. The weights may be variable, i.e., it may vary from period to period or it may be constant over the periods. 
separately.

The existing literature is reviewed in Section II. In Section III, the export and import demand functions are specified and the econometric results are provided and analysed.The last section contains someconcluding remarks.

\section{Previous Estimates of Export and Import Demand Functions for Bangladesh}

In the large literature on the estimation of export and import demand functions, some studies are relevant for Bangladesh. Kabir (1988) estimated aggregate export and import demand functions for Bangladesh using the Cochrane \& Orcutt (1949) method, based on quarterly data from 1973 to 1983 [2]. He found that the income elasticities for both export and import demand functions were expectedly positive, but it was elastic (greater than one) for the import demand function and inelastic for the export demand function. Similarly, the signs of the relative price elasticities were expectedly negative, but greater than one for the export demand function and less than one for the import demand function.

Dutta \& Ahmed (1999) estimated the aggregate merchandise import demand function for Bangladesh based on quarterly data for 1974-1994 [4]. Using Engle \& Granger (1987) cointegration test, they found the existence of longrun relationship between the real quantity of imports, real import prices, real GDP and real foreign exchange reserves [5]. They also found trade liberalization to be an important determinant of the imports of Bangladesh.

Nur et al. (2007) estimated income and price elasticities of export demand for Bangladesh with its Top-5 major destinations (the USA, Germany, UK, France and Belgium) separately, using annual data from 1973 to 2004 and Engle \& Granger (1987) cointegration test approach [16], [5]. They also estimated the impact of trade liberalization on export demand using a dummy variable. They found significant income elasticities with positive (expected) sign and insignificant price elasticities in all cases. Besides, the income elasticities were greater than one with respect to the USA, Germany and France. They found a positive impact of trade liberalization on the exports of Bangladesh.

Wijeweera et al. (2008) estimated income and price elasticities of import demand for Bangladesh with its Top-5 sources of imports (India, Japan, Malaysia, Singapore and the USA) using similar econometric techniques and over the same time period as Nur et al. (2007) [17], [16]. Their main objective was to find whether bilateral income and price elasticities of import demand were significantly different from the aggregate elasticities, estimated earlier. They found that the income and price elasticities of import demand were significantly different between bilateral and aggregate models. In general, the magnitude of disaggregated elasticities was larger than aggregate ones. Secondly, the income elasticity of import demand was insignificant in all cases, except for Malaysia. Thirdly, the impact of exchange rate depreciation on import demand was significantly positive in the case of India and the USA. Finally, the impact of trade liberalization on import demand was positive in all cases.

Aziz \& Horsewood (2008) employed the error correction mechanism to identify the short-term dynamics of the import demand function, and found the impact of real GDP and price on import demand to be statistically significant with expected signs [1]. However, trade liberalization was not found to be significant. Hye \& Mashkoor (2010) estimated the aggregate import demand function of Bangladesh for 1980-2008 using autoregressive distributive lag (ARDL) approach and rolling window method, to find whether cointegration prevailed among the variables of interest and to estimate the income and price elasticities of import demand function [10]. Their results confirmed the long-run relationship between import, income and relative price: income and price elasticities were significantly positive and negative respectively, but they were inelastic (less than one).

Murad (2012) estimated the long-run coefficients of bilateral export and import demand functions of Bangladesh with its six major trading partners (USA, UK, Germany, India, Hong Kong and Japan)from 1973 to 2004, following Johansen (1988) cointegration approach and vector error correction mechanism [15], [12]. He also examined whether the Marshal-Lerner (ML) condition held between Bangladesh and its major trading partners. He found expected long-run relationships among the variables as well as the existence of ML condition in the case of the USA.

Hossain (2013) investigated import demand behavior in Bangladesh within the autoregressive distributive lag (ARDL) modeling framework using annual data from 1973 to 2008 [8]. His empirical results suggested that the import demand function of Bangladesh was stable, income-elastic and price-inelastic. Islam (2016) estimated the elasticities of import and export demand functions for Bangladesh with its traditional partners using annual data from 1981 to 2013 [11]. The results of his ordinary least square estimation suggested that income is the principal determinant of the export and import of Bangladesh, while the exchange rate and the rate of inflation were also important.

This study attempts to estimate bilateral export and import demand functions of Bangladesh with its Top-10 major export and import partners, for the period 1995 to 2015.The Top-10 export and import partners include 16 countries, considering 28 countries of the European Union as a single entity. Out of these 16 countries, 4 countries (the EU, Japan, China and India) are common for both export and import functions, 6 countries (the USA, Canada, Turkey, Australia, Russia and the United Arab Emirates) are used only for the export function, and 6 countries (Singapore, Hong Kong, Indonesia, South Korea, Brazil and Malaysia) are used only for the import function. ${ }^{2}$ These export partners cover about

2 The list of Top-10 major export and import partners along with their respective shares are shown in Figure 3. 
90 per cent of total exports and the import partners cover 75 per cent of total imports of Bangladesh as per data of 2015 (Figure 3). This study adds to the literature because (i) it covers the latest annual data up to 2015, (ii) it covers a greater number of major trading partners compared to the earlier studies, and (iii) it considers the 28 countries of European Union as a single trading partner for both export and import demand functions.

\section{Estimation Procedure and Results}

Income and price are the two principal determinants of any demand function whether it is Marshallian type at the micro level or Keynesian type at the macro level [14], [9]. Since the export and import demand functions reflect macroeconomic phenomena, it is justified to consider national income as the income variable and the relative price (domestic price divided by foreign price) as the price variable in the export and import demand functions. Usually the real GDP and the real exchange rate are used as proxies for income and relative price variables in the export and import demand functions. Theoretically, the export demand of a country is positively influenced by its trading partners' income and negatively influenced by real exchange rate. ${ }^{3}$ On the other hand, the import demand of a country is positively influenced by its own income and real exchange rate. ${ }^{4}$ Therefore, the export and import demand functions in context of Bangladesh are:

$$
\begin{gathered}
X_{t}=\left(Y_{p t}\right)^{\alpha_{1}}\left(R_{t}\right)^{\alpha_{2}} \\
M_{t}=\left(Y_{b t}\right)^{\beta_{1}}\left(R_{t}\right)^{\beta_{2}}
\end{gathered}
$$

where $\mathrm{X}, \mathrm{M}$ and $\mathrm{Y}_{\mathrm{b}}$ indicate the real exports, real imports and real GDP of Bangladesh respectively, $Y_{p}$ indicates the real GDP of partner country, $\mathrm{R}$ indicates the real exchange rate between Bangladesh's taka and partner's currency, $t$ indicates time period, $\alpha_{1}$ and $\alpha_{2}$ indicate income and real exchange rate elasticities of export demand, and $\beta_{1}$ and $\beta_{2}$ indicate income and real exchange rate elasticities of import demand respectively. It is expected that $\alpha_{1}, \beta_{1}$ and $\beta_{2}>0$ and $\alpha_{2}<0$.

To estimate export and import demand functions empirically, I convert this multiplicative form into additive form by taking natural log on both sides and adding constant and error terms.

$$
\ln \mathrm{X}_{\mathrm{t}}=\alpha_{0}+\alpha_{1} \ln \mathrm{Y}_{\mathrm{pt}}+\alpha_{2} \ln \mathrm{R}_{\mathrm{t}}+\mathrm{u}_{\mathrm{t}}
$$

3 Assuming the export goods are normal by nature. The impact of real exchange rate on export demand is negative in the sense that the increase of real exchange rate appreciates domestic currency and raises the price of export goods in terms of foreign currency.

4 Assuming the import goods are normal by nature. The impact of real exchange rate on import demand is positive in the sense that the increase of real exchange rate appreciates domestic currency and reduces the price of import goods in terms of local currency.

$$
\ln \mathrm{M}_{\mathrm{t}}=\beta_{0}+\beta_{1} \ln \mathrm{Y}_{\mathrm{bt}}+\beta_{2} \ln \mathrm{R}_{\mathrm{t}}+\mathrm{v}_{\mathrm{t}}
$$

where $\alpha_{0}$ and $\beta_{0}$ are the constant terms, and $u_{t}$ and $\mathrm{v}_{\mathrm{t}}$ are the error terms in the export and import demand functions respectively.

\subsection{Data Sources}

The deflated value of nominal exports and nominal imports (by export and import price indices) are used as real exports and real imports of Bangladesh. Data on nominal exports and nominal imports are from UNCTADstat, ${ }^{5}$ and the export and import price indices are from Bangladesh Economic Review (BER). ${ }^{6}$ The data on real GDP of Bangladesh and its trading partners are collected from UNCTADstat. The data on real exchange rate is calculated by using equation (5) for all partners, other than the EU, for which equation (6) is used.

$$
\begin{gathered}
\mathrm{R}_{\mathrm{t}}=\left(\frac{\mathrm{ER}_{\mathrm{pc}}}{\mathrm{ER}_{\text {taka }}}\right)_{\mathrm{t}} *\left(\frac{\mathrm{CPI}_{\mathrm{b}}}{\mathrm{CPI}_{\mathrm{p}}}\right)_{\mathrm{t}} \\
\mathrm{R}_{\mathrm{t}}=\left(\frac{\mathrm{WAER}_{\mathrm{euc}}}{\mathrm{ER}_{\text {taka }}}\right)_{\mathrm{t}} *\left(\frac{\mathrm{CPI}_{\mathrm{b}}}{\mathrm{WACPI}_{\mathrm{eu}}}\right)_{\mathrm{t}}
\end{gathered}
$$

where $E R_{\text {taka }}$ and $E R_{\mathrm{pc}}$ indicate the exchange rate of US dollar in terms of Bangladesh taka and partner's currency respectively, $\mathrm{CPI}_{\mathrm{b}}$ and $\mathrm{CPI}$ indicate consumer price index of Bangladesh and its partners respectively, WAER $_{\text {euc }}$ and WACPI ${ }_{\text {eu }}$ indicate the weighted average exchange rate of US\$ in terms of the currencies of EU members and the weighted average consumer price indices of EU members respectively. ${ }^{7}$ The data on exchange rate and the consumer price index $(2005=100)$ are collected from $\mathrm{WDI}^{8}$ and UNCTADstat respectively. Euro conversion rates ${ }^{9}$ are used to convert the exchange rate of euro countries from national currency per US\$ to euro per US\$ for the period when they were not members of the euro area. ${ }^{10}$

\subsection{Stationarity Test}

Although time series data are used heavily in econometric analyses, non-stationarity is a common problem in data. ${ }^{11}$

\footnotetext{
5 World Statistical Database, created by the United Nations Conference on Trade and Development: https://comtrade.un.org/

6 The export and import price indices, published in BER (http://mof.gov.bd/en/), are not in the same base for the period of 1995-2015. So, these are converted into single base: $2005=100$ to make similar to other indices like CPI used in this study. 7 The variable export weights are used in case of export demand functions and the variable import weights are used in case of import demand functions.

8 A publication of the World Bank: http://data.worldbank.org/

9 Collected from the European Central Bank:

http://www.ecb.europa.eu/euro/intro/html/index.en.html

10 The euro area is a monetary union of 19 countries out of 28 members of the European Union.

11 A time series is said to be stationary if its mean, variance and auto-covariance (at various lags) remain the same no matter at what point they are measured, i.e., they are time invariant; otherwise, it is called non-stationary.
} 
This study uses the unit root test for stationarity of time series data, mainly the Dickey-Fuller test and sometimes the Phillips-Perron method when necessary. This required testing the stationarity of 30 data series for export demand functions and 21 data series for import demand functions. ${ }^{12}$ The results are presented in Table 1 and Table 2 for the export and import demand functions respectively, which show that all variables related to export and import demand functions are nonstationary at level form and stationary at first difference form, i.e., they are integrated of order 1, I(1). In other word, they have unit roots.

Table 1. Results of Unit Root Test for Export Demand Functions.

\begin{tabular}{llll}
\cline { 1 - 2 } Variable & \multicolumn{2}{l}{ ADF Test Statistic } & Order of \\
\cline { 1 - 2 } Integration
\end{tabular}

Note: (i) The variable $\mathrm{X}, \mathrm{Y}$ and $\mathrm{R}$ are in natural logarithmic form and they are correspondence to concern export partner. Here the partners are reported by their short name like, EU $=$ European Union. (ii) $* * *, * *$ and $*$ denote significant at $1 \%, 5 \%$, and $10 \%$ level respectively.

12 There are three variables (one dependent variable and two explanatory variables) in each export and import demand function. Ten data series are needed for each variable except the case of import demand functions where one data series on real GDP of Bangladesh is used in all functions.
Table 2. Results of Unit Root Test for Import Demand Functions.

\begin{tabular}{llll}
\hline \multicolumn{1}{l}{ Variable } & \multicolumn{2}{l}{ ADF Test Statistic } & Order of \\
\cline { 1 - 2 } Integration
\end{tabular}

Note: (i) The variable $\mathrm{M}$ and $\mathrm{R}$ are in natural logarithmic form and they are correspondence to concern import partner. Here the partners are reported by their short name, like $\mathrm{CHN}=$ China. The variable YBGD (real income of Bangladesh) is also in logarithmic form. (ii) ${ }^{* * *}, * *$ and $*$ denote significant at 1\%,5\% and 10\% level respectively. @ using Phillips-Perron method.

\subsection{Cointegration Test}

Since the variables are non-stationary at level form, they will produce spurious regression if the ordinary least squares method is applied to estimate export and import demand functions [18]. Since the sample size considered in this study is not so small (21 observations for the period of $1995-2015)^{13}$ and the variables intended to use are integrated in the same order, i.e., I(1), the Johansen method (a multivariate generalization of the augmented Dickey-Fuller test which starts from the Vector Autoregression or VAR) was applied to test whether the variables in export and import demand functions are cointegrated or not. This was applied on 20 functions separately. The results of cointegration test along with the optimal number of lags are shown in Table 3. It is observed that there is long-run relationship among the variables used in the export and import demand functions of Bangladesh. Specifically, the real export of Bangladesh, real income of the partner country and the real exchange rate of Bangladesh taka against partner currency have long-run association among themselves and they influence one another in the long-run. The same characteristics prevailed for real imports of Bangladesh, real income of Bangladesh and the real exchange rate of Bangladesh taka against the partner currency.

13 The data on export and import of Bangladesh are very different in different sources. Among them, the data of UNCTADstat that covers all merchandise products looks very reliable. Therefore, this study collects both export and import data from UNCTADstat which have started from 1995. 
Table 3. Results of Johansen's Test of Cointegration.

\begin{tabular}{llll}
\hline \multirow{2}{*}{ Partner } & No. of Cointegrating Equation(s) & Decision \\
\cline { 2 - 4 } & Trace Test & Max-Eigenvalue Test & Cointegrated \\
\hline Export Demand Function & 1 & 1 & Cointegrated \\
European Union (1) & 1 & 1 & Cointegrated \\
United States (2) & 1 & 1 & Cointegrated \\
Canada (1) & 1 & 1 & Cointegrated \\
Japan (1) & 1 & 1 & Cointegrated \\
Turkey (1) & 1 & 1 & Cointegrated \\
China (1) & 1 & 1 & Cointegrated \\
Australia (1) & 1 & 1 & Cointegrated \\
India (1) & 1 & 1 & Cointegrated \\
Russia (2) & 1 & 1 & Cointegrated \\
United Arab Emirates (2) & & & Cointegrated \\
Import Demand Function & 1 & 1 & Cointegrated \\
China (1) & 1 & 1 & Cointegrated \\
India (2) & 1 & 1 & Cointegrated \\
European Union (1) & 1 & 1 & Cointegrated \\
Singapore (2) & 1 & 1 & Cointegrated \\
Japan (1) & 1 & 1 & Cointegrated \\
Indonesia (1) & 1 & 1 & Cointegrated \\
South Korea & 1 & 1 & Cointegrated \\
Malaysia (1) & 1 & 1 & Cointegrated \\
Brazil (2) & 1 & 1 & Hong Kong (1)
\end{tabular}

Note: Figures in the parentheses indicate optimal number of lag(s).

\subsection{Vector Error Correction Model}

It is important to test the impact of short-run disturbances on the long-run relationship (i.e., the test of the stability of long-run relationship) as well as to know the direction and magnitude of the long-run relationship among the variables, in other words, to know the long-run coefficients of the cointegrating equations. Therefore, the vector error correction model ${ }^{14}$ was estimated for the export and import demand functions of Bangladesh. The results are depicted in Table 4.

Table 4. Long-run Coefficients and the Speed of Adjustment.

\begin{tabular}{lllll}
\hline Partner & \multicolumn{2}{l}{ Long-Run Coefficients } & ECT \\
\hline & In Y & In R & Constant & \\
\hline Export Demand Function & & & & \\
European Union (1) & $3.04^{* *}$ & 0.20 & 54.43 & $-0.15^{* *}$ \\
United States (2) & $0.84^{* * *}$ & $1.19^{*}$ & 11.32 & $-0.37^{* *}$ \\
Canada (1) & $2.68^{* *}$ & $-3.05^{* *}$ & 30.84 & $-0.21^{* * *}$ \\
Japan (1) & $7.99^{*}$ & $4.54^{*}$ & 138.66 & $-0.20^{* *}$ \\
Turkey (1) & $2.67^{* *}$ & $-3.43^{* *}$ & 13.69 & $-0.44^{* * *}$ \\
China (1) & $0.30^{* * *}$ & 2.15 & -9.23 & $-0.14^{* *}$ \\
\hline
\end{tabular}

14 The Vector Error Correction Model (VECM) is restricted VAR model that can run if the variables (in level form) considered in the model are cointegrated. In VECM, the first difference form (instead of level form) of every variable is considered as endogenous and they depend on five types of exogenous variables, such as constants, lag value(s) of their own first difference form, lag values of the first difference forms of other variables, corresponding cointegrating equation(s) and the error term. Among all coefficients corresponding to five types of exogenous variables, the coefficient of the cointegrating equation is very important. This coefficient is called Error Correction Term (ECT) or speed of adjustment, which indicates how quickly the long-run relationship of the variables is regained after any short-run disturbance. The ECT should be significant along with negative sign for such adjustment. In addition to ECT, the VECM estimates the coefficients of cointegrating equation (long-run coefficients).

\begin{tabular}{lllll}
\hline Partner & \multicolumn{2}{l}{ Long-Run Coefficients } & ECT \\
\hline & In Y & In R & Constant & \\
\hline Australia (1) & $4.55^{* *}$ & $6.92^{*}$ & 183.71 & $-0.05^{* *}$ \\
India (1) & $1.70^{* * *}$ & $-0.68^{* * *}$ & -15.41 & $-1.25^{* * *}$ \\
Russia (2) & $3.88^{* *}$ & $-3.18^{* *}$ & 34.01 & $-0.43^{* * *}$ \\
United Arab Emirates (2) & $3.22^{* *}$ & $12.48^{*}$ & 33.25 & $-0.54^{* *}$ \\
Import Demand Function & & & & \\
China (1) & $1.64^{* * *}$ & $-2.57^{*}$ & -1.13 & $-0.46^{* *}$ \\
India (2) & $1.98^{* * *}$ & $4.37^{* *}$ & 34.89 & $-0.11^{* * *}$ \\
European Union (1) & $0.86^{* * *}$ & $-0.93^{*}$ & -2.01 & $-1.57^{* *}$ \\
Singapore (2) & $1.59^{* * *}$ & $2.65^{* *}$ & -5.65 & $-0.22^{* *}$ \\
Japan (1) & $0.84^{* * *}$ & $0.76^{* * *}$ & 2.83 & $-0.71^{* * *}$ \\
Indonesia (1) & $1.51^{* * *}$ & $-0.51^{*}$ & 8.68 & $-0.66^{* *}$ \\
South Korea (1) & $1.78^{* * *}$ & $1.93^{* * *}$ & 1.73 & $-0.23^{* * *}$ \\
Malaysia (1) & $2.09^{* *}$ & $-4.10^{*}$ & -17.73 & $-0.23^{* *}$ \\
Brazil (2) & $2.36^{* *}$ & $-0.66^{*}$ & 36.13 & $-0.39^{* *}$ \\
Hong Kong (1) & $2.48^{* *}$ & $8.28^{* *}$ & -8.38 & $-0.31^{* * *}$ \\
\hline
\end{tabular}

Note: Figures in the parentheses indicate optimal number of $\operatorname{lag}(\mathrm{s})$. ***, *** and $*$ indicate significant at $1 \%, 5 \%$ and $10 \%$ level.

Table 4 shows the long-run coefficients of real GDP (Column 2) and real exchange rate (Column 3), and the error correction terms (last column) for bilateral export and import demand functions of Bangladesh. The error correction terms are significant with expected (negative) sign indicating that any short-run disturbance on the long-run movement of the variables is removed by the magnitude of the error correction terms. In case of export demand function with respect to the EU and the USA (for example), the annual correction rates are 15 per cent and 37 per cent respectively. That means that the existence of a long-run relationship, ensured by the Johansen cointegration test, is not hampered by any short-run disturbance.

The real GDP coefficients (which can be interpreted as income elasticity of demand) with respect to all export and 
import demand functions are significant with expected (positive) sign, but the real exchange rate coefficients (used as proxy for price elasticity) are not. The real GDP coefficients are not only significant with positive sign but also elastic (greater than 1) in most of the cases. Out of 10 export demand functions, the real GDP coefficients are elastic in 8 cases, except for the United States and China. This result indicates that the export demand for Bangladeshi products is highly influenced by economic growth in partner countries. So the business cycles of those countries affect export demand of Bangladesh. This result validates much of the existing literature [16], [11] and is as expected given the nature of Bangladeshi export products, since the main export item - readymade garments - is likely to be income elastic in demand. But in case of China, the income elasticity for Bangladesh's exports is very low (0.30), probably because China is not a major RMG importer; rather she is the largest RMG exporter internationally.

Like the export demand function, the real GDP coefficients of the import demand functions are elastic in most of the cases (8 out of 10) except the European Union and Japan, which are near unity. This is similar to the existing literature [1], [10]. Therefore, domestic economic growth is an important factor for import demand in Bangladesh. But this may not be because of final consumption, as the nature of import goods indicates. As Figure 2 shows, textile and clothing (mostly raw materials for apparel industries) is the largest import item of Bangladesh (24 per cent of total imports) followed by machinery and electronics (18 per cent of total imports). The demand for Bangladesh's imports mostly depend on activity in the export-oriented manufacturing sector, which obviously then contributes to aggregate output.

Among the real exchange rate coefficients, some are significant with expected sign, some are significant with unexpected (opposite) sign and some are insignificant with unexpected sign. In case of the export demand function, 4 coefficients are significant with expected (negative) sign against Canada, Turkey, India and Russia; 4 coefficients are significant with unexpected (positive) sign against the United States, Japan, Australia and the United Arab Emirates; and 2 coefficients against the European Union and China are neither significant nor negative. The real exchange rate coefficients that are significant with expected sign cover only 10 per cent of total exports of Bangladesh (Figure 3). These results suggest that the real exchange rate is not an important determinant of export demand for Bangladesh. Although this estimated result is supported by some existing literature [16], it is unexpected and obviously of great interest to policy makers.

Several factors may be at work in this regard. First, it should be noted that the consumer price indices used in the construction of the bilateral real exchange rates incorporate the prices of both tradable and non-tradable goods. Among the tradable goods, some goods are exportable and some goods are imported. Ideally, there should be further disaggregation, for example, it would appropriate to use the export price index of Bangladesh and the consumer price index of the partner country that are constructed considering the commodities exports from Bangladesh to that particular trading partner to estimate the bilateral real exchange rate for exports. But such data are not available in the existing sources.

Second, the export demand for Bangladeshi products does not depend only on bilateral relative prices, but also on the prices of her competitors. As Figure 4 depicts, Bangladesh shows the lowest unit value index of exports among the major RMG exporters. This gives such an absolute price advantage that small changes in real exchange rate may not have much impact. ${ }^{15}$ The main reason for this is the existence of cheap labour in Bangladesh. According to Cowgill et al. (2015), Bangladesh is in the second cheapest country after Sri Lanka (among Top-20 apparel exporters) in terms of monthly minimum wages paid to the apparel workers (Figure 5 ), who are mostly women with low reservation wages in an already surplus labour market [3].

Third, the facility of the generalized system of preference (GSP) and government incentives to exporters have enabled Bangladesh to provide its products at comparatively low price to the consumers of many countries. Under the GSP facility, Bangladesh, as a Least Developed Country, has enjoyed duty free market access or reduced tariff rate facilities to export to various developed and developing countries since the 1970s. At present, Bangladesh gets GSP facility from 38 countries including 28 members of the European Union. ${ }^{16}$ However, from June 2013, Bangladesh was temporarily out off from the GSP facility of the USA on the grounds of workers' rights.

In case of the import demand function, 5 real exchange rate coefficients with respect to India, Singapore, Japan, South Korea and Hong Kong are significant with expected (positive) sign and 5 coefficients with respect to China, the EU, Indonesia, Malaysia and Brazil are significant with opposite (negative) sign. The real exchange rate coefficients that are significant with expected sign cover only 28 per cent of the total imports of Bangladesh. Therefore, the real exchange rate is not an important determinant of Bangladesh's import demand. As in the case of export demand, using the consumer price index in the construction of real exchange rate is one of the reasons for such a result. For import demand, it would be more appropriate to use the export price index of the partner country and the consumer price index of Bangladesh (considering the commodities that are imported by Bangladesh from the particular partner) in constructing the bilateral real exchange rate.

Second, trade-based money laundering is another important reason for observed absence of price impact on the import demand of Bangladesh. According to Global Financial

15 The unit value index shown in Figure 4 is not constructed considering only RMG products specifically; rather it considers all export products of the country. But RMG covers 85 percent of total export products of Bangladesh.

16 The other 10 countries are Australia, Belarus, Canada, Liechtenstein, Japan, New Zealand, Norway, Russian Federation, Switzerland and Turkey (Source: Export Promotion Bureau of Bangladesh). 
Integrity (2017), illicit financial flows of Bangladesh amounted to 17 per cent of total trade (US\$446153 million) during 2005-2014, of which 12 per cent reflected trade misinvoicing [6]. The drastic trade liberalization (without proper monitoring) expedited money laundering in Bangladesh. The weighted average MFN tariff rate fell from
62.7 per cent in 1994to 12.9 per cent in 2015 (Source: WITS), while the number of restricted products (at 4-digit HS code) reduced from 109 in 1994to 26 in 2015 (Source: BER). In addition, many export oriented industries enjoy zero tariff rates for the import of their industrial raw materials and capital machinery.

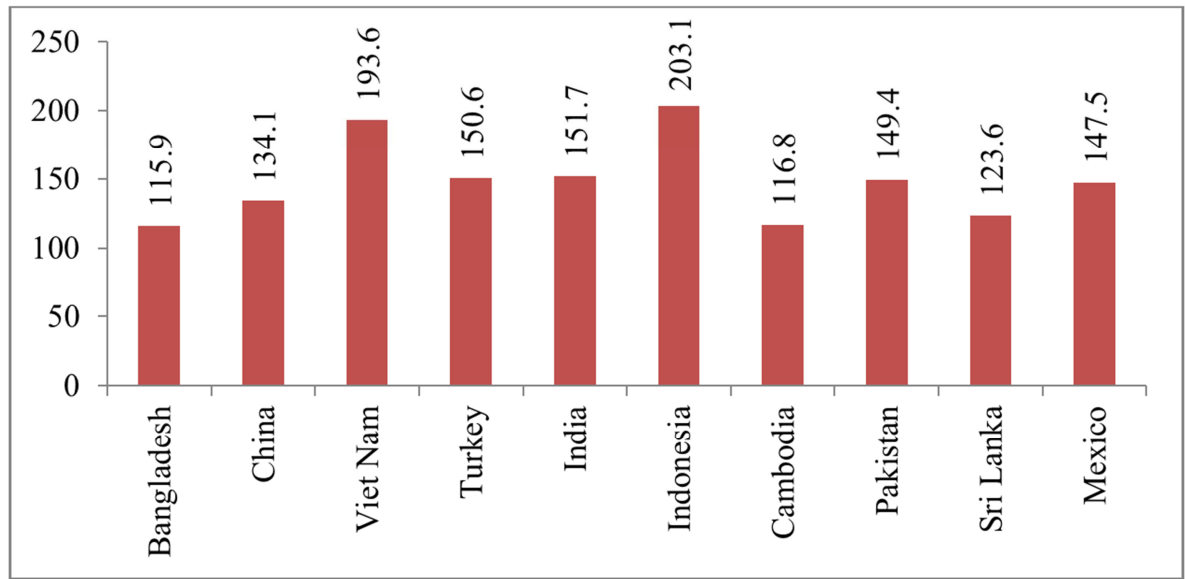

Source: Prepared on the basis of data from UNCTADStat (Base: $2005=100$ ).

Figure 4. Unit Value Index of Exports in 2015.

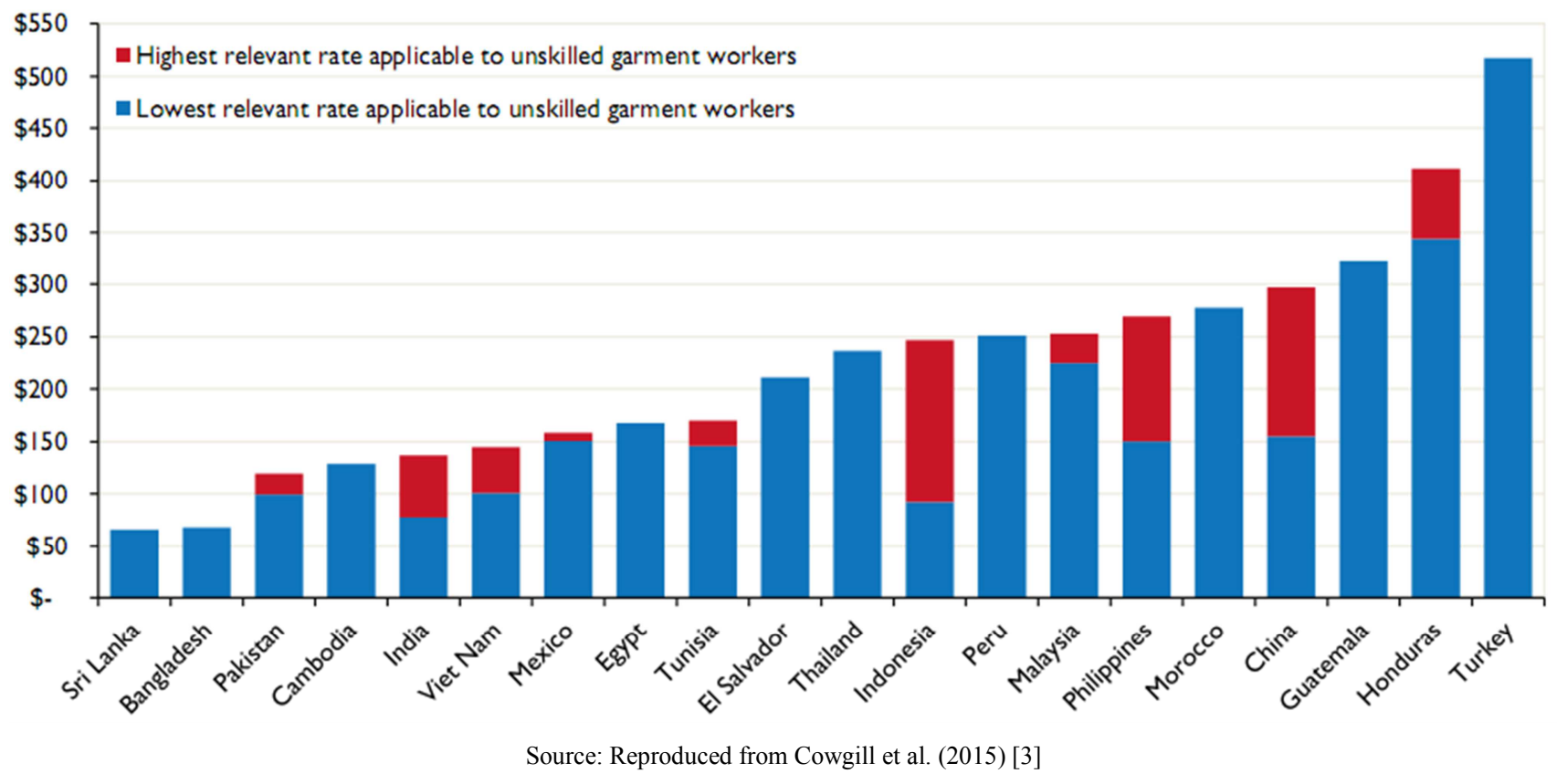

Figure 5. Monthly Minimum Wages in the Top-20 Apparel Exporters as of 1 January 2015.

\section{Concluding Remarks}

Bangladesh has historically been a trade deficit country. In the first two decades after independence, this was due to the combination of low exports and high dependence on the import of consumer goods, mainly food products. Subsequently, the pattern of imports shifted from consumer goods to industrial raw materials. Now the production of country's export goods, mainly readymade garments, is highly dependent on the imports of industrial raw materials and capital machinery. As a result, the trade deficit as per cent of GDP did not reduce, although both export and import as per cent of GDP increased greatly over the years.

This study focused on estimating export and import demand functions, so as to find out the principal determinants of export and import demand on bilateral basis. The cointegration test pointed to the existence of long-run relationship among the variables in the export and import demand functions, and the estimated error correction term ensured the stability of the long-run relationship. The result showed that income elasticities are significant with expected sign in all cases, while the price elasticities are not significant 
in most of the cases. The real exchange rate (used as proxy of relative price) coefficients that are significant with expected sign represent only 10 per cent of total exports and 28 per cent of total imports of Bangladesh.

Probable reasons for this unexpected price effect include the level of aggregation in calculating the real exchange rate; the fact that Bangladesh's main export (garments) is so low priced internationally (because of cheap labour) that exchange rate changes cannot affect exports much; the GSP facility as well as the government cash incentives that make Bangladeshi products more competitive in the international market; and the existence of trade based money laundering, which has been expedited by trade liberalization.

The results for the export demand functions suggest that the income effect is one of the main reasons for the concentration of Bangladesh's exports to some developed countries, specifically in Europe and America.

\section{Acknowledgements}

This paper is based on Ph.D. research. The author is indebted to Professor Jayati Ghosh for her valuable guidance and suggestions. The earlier version of this paper was presented in the CESP-CAS Young Scholars' Conference organized by Centre for Economic Studies and Planning, Jawaharlal Nehru University from 26-28 March, 2017. The author also acknowledges the suggestions and feedbacks of the discussant and the participants of the conference.

\section{References}

[1] Aziz, N. \& Horsewood, N. J. (2008). Determinants of Aggregate Import Demand of Bangladesh: Cointegration and Error Correction Modelling. In The 18th International Conference (May 21-24). International Trade and Finance Association, Lisbon, Portugal.

[2] Cochrane, D. \& Orcutt, G. H. (1949). Application of Least Squares Regression to Relationships Containing AutoCorrelated Error Terms. Journal of the American Statistical Association, 44 (245), 32-61.

[3] Cowgill, M., Luebker, M. \& Xia, C. (2015). Minimum Wages in the Global Garment Industry: Update for 2015. International Labour Organization.

[4] Dutta, D. \& Ahmed, N. (1999). An aggregate import demand function for Bangladesh: A cointegration approach. Applied Economics, 31(4), 465-472.
[5] Engle, R. F. \& Granger, C. W. J. (1987). Co-integration and Error Correction: Representation, Estimation, and Testing. Econometrica, 55(2), 251-276.

[6] Global Financial Integrity. (2017). Illicit Financial Flows to and from Developing Countries: 2005-2014.

[7] Goswami, G. G. \& Sarker, M. M. I. (2010). Exchange Rate Sensitivity of Inpayments and Outpayments of Bangladesh: An Aggregate vs. Bilateral Approach. Bank Parikrama, $X X X V$, $38-59$.

[8] Hossain, A. A. (2013). Trade Liberalization and ImportDemand Behavior in Bangladesh, 1974-2008. The Journal of Developing Areas, 47(2), 387-416.

[9] Houthakker, H. S. \& Magee, S. P. (1969). Income and Price Elasticities in World Trade. The Review of Economics and Statistics, 51(2), 111-125.

[10] Hye, Q. M. A. \& Mashkoor, M. (2010). Import Demand Function for Bangladesh: A Rolling Window Analysis. African Journal of Business Management, 4(10), 2150-2156.

[11] Islam, T. (2016). An Empirical Estimation of Export and Import Demand Functions Using Bilateral Trade Data: The Case of Bangladesh. Journal of Commerce \& Management Thought, 7(3), 526-551.

[12] Johansen, S. (1988). Statistical Analysis of Cointegrating Vectors. Journal of Economic Dynamics and Control, 12, 231-254.

[13] Kabir, R. (1988). Estimating Import and Export Demand Function: The Case of Bangladesh. The Bangladesh Development Studies, 16(4), 115-127.

[14] Kreinin, M. E. (1967). Price Elasticities in the International Trade. The Review of Economics and Statistics, 57, 221-224.

[15] Murad, S. M. W. (2012). Bilateral Export and Import Demand Functions of Bangladesh: A Cointegration Approach. The Bangladesh Development Studies, XXXV(1), 43-60.

[16] Nur, M., Wijeweera, A. \& Dollery, B. (2007). Estimation of the Export Demand Function using Bilateral Trade Data: The Case of Bangladesh. South Asia Economic Journal, 8(2), 249264.

[17] Wijeweera, A., Nur, M. \& Dollery, B. (2008). Bilateral Import Demand Elasticities the Case of Bangladesh. International Research Journal of Finance \& Economics, (19), 114-125.

[18] Yule, G. U. (1926). Why do we Sometimes get NonsenseCorrelations between Time-Series? --A Study in Sampling and the Nature of Time-Series. Journal of the Royal Statistical Society, 89(1), 1-63. 